\title{
Corrosion inhibition of MNZh alloy with sodium salts of lower dicarboxylic acids in neutral aqueous solution ${ }^{1}$
}

\author{
M.O. Agafonkina, (iD I.A. Kuznetsov, (iD* Yu.I. Kuznetsov, (i) \\ O.Yu. Grafovii and N.P. Andreeva \\ ${ }^{1}$ A.N. Frumkin Institute of Physical Chemistry and Electrochemistry, Russian Academy \\ of Sciences, Leninskii pr. 31, 119071 Moscow, Russian Federation \\ *E-mail: anarenen@gmail.com
}

\begin{abstract}
The adsorption, protective and passivating effect of sodium salts of dicarboxylic acids on the oxidized surface of copper-nickel alloy MNZh 5-1 and on its individual components in a neutral chloride solution has been studied. It is shown that sodium adipate has a higher free energy of adsorption $\left(-\Delta G_{\text {ads }}^{0}\right)$ on the MNZh 5-1 alloy at $E=0.0 \mathrm{~V}$ than sodium malonate and ethylmalonate. The values of $-\Delta G_{\text {ads }}^{0}$ are $81.8,74.1$, and $78.1 \mathrm{~kJ} / \mathrm{mol}$, respectively, which suggests the chemisorption interaction of these organic anions with the oxidized surface of the alloy. The elemental composition of the alloy surface was determined by the XPS method, in a borate buffer at different electrode potentials. It is shown that at the free corrosion potential, the surface of the copper-nickel alloy is enriched with iron, which reduces the resistance of the alloy to the action of chloride ions. Corrosion tests of the alloy in water, containing $10 \mathrm{mmol} / \mathrm{L}$ $\mathrm{NaCl}$ for 7 days showed that the formulation of sodium adipate with 2-mercaptobenzthiazole $(9: 1)$ at $3 \mathrm{mmol} / \mathrm{L}$ is capable of providing full protection of the alloy. The addition of only adipate itself at the indicated concentration makes it possible to achieve only $Z=49 \%$.
\end{abstract}

Keywords: copper alloy, sodium malonate, dicarboxylic acids, adsorption, neutral chloride solution, ellipsometry, Temkin isotherm, XPS.

Received: February 20, 2020. Published: March 11, 2021

doi: $\underline{10.17675 / 2305-6894-2020-10-1-20}$

\section{Introduction}

Increased requirements for the reliability of condensers and heat exchangers at TPPs and NPPs cause designers to pay attention to pipe corrosion. Along with various methods of protecting them from corrosion damage, the right choice of pipe material depending on the properties of the cooling water, taking into account design, operational and economic factors, is of paramount importance. In domestic and foreign practice, copper and copper alloys pipes are widespread, since they have high thermal conductivity. Low cost and satisfactory service life predetermined their widespread use.

\footnotetext{
${ }^{1}$ This work was carried out with partial financial support from the Russian Foundation for Basic Research (Grant No. 20-03-00101 "Adsorption of anions of dicarboxylic acids on copper and its alloys and their passivation in neutral solutions").
} 
For non-aggressive cooling water, the use of cheap tin brass LO-70-1 is quite common in European countries, and the copper-nickel alloy MNZh-5-1 is more common in Russia. Brass brands LO-70-1 contain 70\% copper, $1 \%$ tin and the rest zinc. For this reason, in foreign papers it is difficult to find studies of corrosion inhibition of the MNZh 5-1 alloy, but there are many works on the protection of bronze in media with different $\mathrm{pH}$ : acidic [13], neutral chloride [4-7] and alkaline [8].

In all these cases, organic compounds containing nitrogen, sulfur, or phosphorus heteroatoms [9] or their synergistic mixtures from different classes of organic compounds [7] or with metal cations [10] are used as corrosion inhibitors (CIs).

Investigations on the corrosion inhibition of the MNZh 5-1 alloy in neutral chloride solutions were carried out by us using CIs belonging to different classes of organic compounds, such as azoles [11, 12], salts of carboxylic [13] and dicarboxylic acids [14, 15].

1,2,3-Benzotriazole (BTA) is one of the long and widely known inhibitors of copper corrosion, which is the basis of the MNZh 5-1 alloy [16]. Even more effective than BTA, as shown recently [12], 5-chloro-BTA protects copper and its alloy MNZh-5-1 from corrosion. The disadvantage of BTA and its substituted ones is that it is difficult to classify them as ecologically safe and non-toxic CI, although, of course, they are not as dangerous as chromates. In this regard, sodium salts of carboxylic acids, which can be effective CIs of copper and its alloys, deserve attention.

For example, sodium salts of non-toxic lauric acid $\mathrm{CH}_{3}\left(\mathrm{CH}_{2}\right)_{10} \mathrm{COONa}(\mathrm{SL})$, which are part of many animal and vegetable fats, and oleylsarcosine $\mathrm{CH}_{3}\left(\mathrm{CH}_{2}\right)_{7} \mathrm{CH}=\mathrm{CH}\left(\mathrm{CH}_{2}\right)_{7} \mathrm{CON}\left(\mathrm{CH}_{3}\right) \mathrm{CH}_{2} \mathrm{COONa}$ (SOS) [13], can be used to protect MNZh 5-1 against corrosion. Their adsorption, measured on this alloy in a borate buffer solution of $\mathrm{pH} 7.4$ at $E=0.0 \mathrm{~V}$ by the in situ ellipsometric method, is described by the complete Temkin equation with free adsorption energies of $-\Delta G_{\mathrm{ads}}^{0}=72.3$ and $78.6 \mathrm{~kJ} / \mathrm{mol}$, respectively, i.e., significantly higher than in the case of BTA adsorption: $-\Delta G_{\mathrm{ads}}^{0}=$ $64 \mathrm{~kJ} / \mathrm{mol}$. Both CIs are chemisorbed on the alloy surface and are in a nearly flat position. In addition, the adsorption of SOS on the alloy is polymolecular, even at very low $C_{\text {inh }}$ concentrations.

Recently, in [14], we studied the adsorption on oxidized copper of three sodium salts of lower dicarboxylic acids ( $\mathrm{NaOOCCH} \mathrm{COONa}_{2}$ - malonate, $\mathrm{NaOOCCH}\left(\mathrm{C}_{2} \mathrm{H}_{5}\right) \mathrm{COONa}-$ ethylmalonate, and $\mathrm{NaOOC}\left(\mathrm{CH}_{2}\right)_{2} \mathrm{COONa}$ - succinate) from borate solution with $\mathrm{pH}$ 7.4. Such compounds, containing two carboxyl groups, do not pose an environmental hazard, since they are found in nature in free form (green parts of plants and sap) and if they show protective properties, they can be classified as "green CI". It turned out that they can be strongly adsorbed on the oxidized copper surface from a neutral buffer solution. The $-\Delta G_{\text {ads }}^{0}$ values, calculated by the equation of the complete Temkin isotherm, are equal to 47.7, 69.4 and $77.4 \mathrm{~kJ} / \mathrm{mol}$, respectively. It can be assumed that the high adsorption capacity of these anions is due to the participation of both carboxy groups of these anions in their chemisorption process with the copper surface. For malonates, this interaction should also be facilitated by the close spatial arrangement of carboxyl groups in their molecules. 
However, salts of lower dicarboxylic acids are rarely used as CIs, since compounds with a short chain of up to 3 carbon atoms behave as weak CIs of copper, steel, and aluminum in aerated, almost neutral and slightly mineralized aqueous solutions [17]. Starting from 4 carbon atoms in the chain and up to 12, the protective properties of dicarboxylates increase and then strongly decrease at 14 carbon atoms. Such abrupt changes in the CI efficiency are probably the results of competing processes of adsorption and complexation on the metal surface (hydroxide/oxide), solubility, and the formation of micelles in solution.

In [18], during corrosion tests in a water-glycol solution (glycol content 50\% by weight), it was shown that on copper and bronze, according to the metal inhibition efficiency, the studied salts of carboxylic acids can be arranged in the following sequence: sodium sebacate $\left(\mathrm{Na}_{2} \mathrm{C}_{10} \mathrm{H}_{16} \mathrm{O}_{4}\right)>$ sodium adipate $\left(\mathrm{Na}_{2} \mathrm{C}_{6} \mathrm{H}_{8} \mathrm{O}_{4}\right)>$ sodium succinate $\left(\mathrm{Na}_{2} \mathrm{C}_{4} \mathrm{H}_{4} \mathrm{O}_{4}\right)$. Based on these results, the authors came to the conclusion that with an increase in the length of the hydrocarbon chain of dicarboxylic acids, the protective effect of salts increases with respect to non-ferrous metals.

The aim of this work is to reveal the features of the adsorption of anions of salts of malonic, ethylmalonic and adipic acids (Figure 1) on the oxidized surface of the MNZh 5-1 alloy, copper, nickel and iron. Corrosion tests and assessment of the possibility of protecting the alloy with these CIs in neutral chloride solutions. The XPS method will be used to study the composition of the alloy surface depending on the potential of the electrode in a neutral solution.

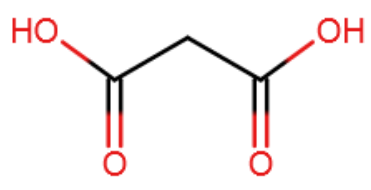

a)

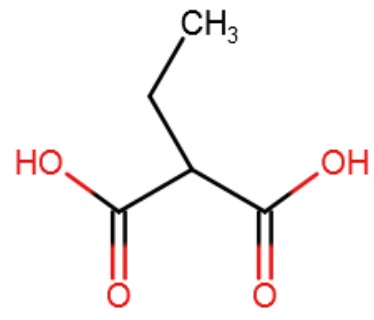

b)

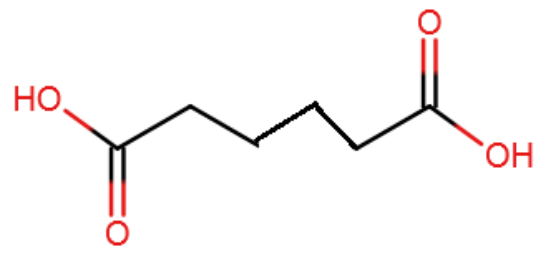

c)

Figure 1. Structure formulae of a) malonic, b) ethylmalonic and c) adipic acid.

\section{Experimental}

The work was carried out on electrodes made of MNZh 5-1 alloy, which contains $\mathrm{Cu}$ : 90.693.7\%, Ni+Co: 5.0-6.5\%, Fe: 1.0-1.4\%, Mn: 0.3-0.8\%, $\mathrm{Zn}<0.5 \%$, Si: <0.15\%, Sn: $<0.1 \%$, P: $<0.04 \%$ and S: $<0.01 \%$ (GOST 492-2006), nickel, brand $\mathrm{H} 0$ and low-carbon steel St3: Fe: 97\%, C: 0.14-0.22\%, Si: 0.15-0.30\%, Mn: 0.40-0.65\%, Ni: <0.3\%, S: <0.05\%, P: $<0.04 \%$, Cr: <0.3\%, Cu: <0.3\% (GOST 380-2005).

The studies used compounds purchased from Sigma Aldrich - malonic acid (CAS Number 141-82-2), its substituted derivative ethylmalonic acid (CAS Number 601-75-2), and sodium adipate (CAS Number 7486-38-6). 
Malonic and ethylmalonic acids were converted into sodium salts by neutralization with a sodium hydroxide solution; the $\mathrm{pH}$ of the working solutions was maintained in the range 6.4-7.4. For ellipsometric measurements, dilute solutions of $10^{-8}-10^{-10} \mathrm{M}$ were used; for electrochemical and corrosion studies, a concentrate of 0.05 and $0.10 \mathrm{M}$ was prepared.

The studies of CIs adsorption on the oxidized metal surface were carried out on an RR 2000 manual ellipsometer in an electrochemical cell, which simultaneously allows maintaining the electrode potential $E$ set from the potentiostat and measuring the ellipsometric phase shift angle $\Delta$. Accuracy in determining the angle equals $\pm 0.05^{\circ}$. Potential of the oxidized electrode surface $E=0.0 \mathrm{~V}$ (SHE) for copper and MNZh 5-1 alloy, $E=0.2 \mathrm{~V}$ for St 3 and nickel. The potentials $E$ of the electrode in the solution were measured relative to the silver chloride reference electrode; in the article, their values are given in terms of a standard hydrogen electrode.

From the solution of the basic equation of ellipsometry [19] it follows that in the region of small thicknesses (up to $10 \mathrm{~nm}$ ), changes in the ellipsometric phase shift angle $\Delta$ are proportional to the film thickness $d$ :

$$
d=-\alpha \delta \Delta=-\alpha\left(\Delta-\Delta_{0}\right)
$$

where $\alpha$ is the proportionality coefficient, $\Delta_{0}$ is the angle value for the original surface, and $\Delta$ is the angle value during the experiment.

To obtain the adsorption isotherm of compounds, a concentrate of the inhibitor under study was added in portions to a cell with a borate buffer solution of $\mathrm{pH}$ 7.4. For each concentration of $C_{\mathrm{inh}}$, the angle $\Delta$ decreases with time and stops changing after 90-120 min. Thus, we determine the difference in angles $(-\delta \Delta)$ to plot its dependence on $C_{\text {inh. }}$. The value of $C_{\mathrm{inh}}$, at which the change in the angle $\Delta$ stops, corresponds to the formation of a monolayer, while the degree of filling of the electrode surface by the adsorbate is $\theta \rightarrow 1$. The experimental dependence of the change in the angle $\Delta$ on $\log C_{\mathrm{inh}}$ is rearranged into an adsorption isotherm $\theta=f(\ln C)$ and the free adsorption energy $\left(-\Delta G_{\text {ads }}^{0}\right)$ is calculated.

The adsorption of these compounds is adequately described by the complete Temkin equation:

$$
\theta=\frac{1}{f} \ln \frac{1+B_{\max }(C)}{1+B_{\min }(C)}
$$

where $f$ is the surface heterogeneity factor, characterizing the change in the enthalpy of adsorption with the filling of the surface; $B_{\max }$ and $B_{\min }$ are the adsorption equilibrium constants corresponding to the highest and lowest values of the adsorption energy. The quantity $B$ is related to the free energy of adsorption $\left(-\Delta G_{\mathrm{ads}}^{0}\right)$ as follows:

$$
B_{\max (\min )}=\exp \left[\left(-\Delta G_{a, \max (\min )}^{0}\right) / R T\right]
$$

To determine $-\Delta G_{\text {ads }}^{0}, f, B_{\max }$, and $B_{\min }$, we used the method described earlier [20]. 
Electrochemical studies consisted of recording anodic polarization curves in a borate buffer solution with the addition of $0.01 \mathrm{M} \mathrm{NaCl}$. These curves were recorded on MNZh 5-1, nickel, and St3 electrodes in an electrochemical cell with separated electrode spaces on an IPC-Pro MF potentiostat (RF). The working electrode was preliminarily polished on emery papers of various grain sizes 360-1000 and then degreased with acetone.

After removing the air-formed film of mixed metal oxides on the alloy (holding the electrode for $15 \mathrm{~min}$ in a borate buffer of $\mathrm{pH} 7.4$ with $0.01 \mathrm{M} \mathrm{NaCl}$ at $E=-0.60 \mathrm{~V}$ ), nickel and St 3 at $E=-0.65 \mathrm{~V}$ ), the potentiostat was turned off until the free corrosion potential $E_{\text {cor }}$ was established. After the establishment of a new value of $E_{\text {cor }}$, formed during the adsorption of organic molecules of $\mathrm{CI}$ introduced into the buffer solution on the electrode, polarization curves were recorded with a potential scan rate of $0.2 \mathrm{mV} / \mathrm{s}$. Two series of polarization measurements were carried out on the MNZh 5-1 alloy: exposure in a chloride buffer solution with $\mathrm{CI}$ for $15 \mathrm{~min}$ and $1 \mathrm{~h}$.

The potential of local depassivation $\left(E_{\mathrm{ld}}\right)$ of the metal by chlorides was determined from a sharp increase in the current on the polarization curve with subsequent visual identification of pitting on the electrode surface. The error in measuring $E_{\mathrm{ld}}$ is $0.01 \mathrm{~V}$.

XPS spectra of surface layers were recorded on an OMICRON ESCA+ spectrometer (OMICRON, Germany). The pressure in the chamber of the OMICRON ESCA+ analyzer was maintained no higher than $8 \cdot 10^{-10} \mathrm{mbar}$, the source of radiation was the $\mathrm{Mg}$ anode $\left(\mathrm{Mg} K_{\alpha} 1253.6 \mathrm{eV}\right)$. The transmission energy of the analyzer was $20 \mathrm{eV}$, the scanning step of the binding energy was $0.05 \mathrm{eV} / \mathrm{s}$. The spectra were decomposed into components using the UNIFIT 2009 program after subtracting the background determined by the Shirley method [21]. The ratios of elements on the surface of the samples were calculated using the integral intensities under the peaks taking into account the photoionization cross sections $\sigma$ of the corresponding electron shells [22].

Samples for research were plates made of MNZh 5-1 alloy, size $25 \times 40 \mathrm{~mm}$. For a quantitative analysis, regions with binding energies characteristic of the main elements of the alloy: $\mathrm{Cu} 2 \mathrm{p} 3 / 2(942-926 \mathrm{eV}), \mathrm{Fe} 2 \mathrm{p} 3 / 2(725-700 \mathrm{eV})$ and Ni2p3/2 (867-847 eV) were analyzed. Before the study, the samples were sanded with P1000-2500 emery paper, then polished with diamond paste (TedPella, inc. $0.25 \mu \mathrm{m}$ ) to a mirror surface, degreased with ethanol and washed in an ultrasonic bath. Then the plates were placed in a working cell with a borate buffer, on which the potential was maintained using a computerized potentiostat. The cathodic polarization of the electrode was carried out at $E=-0.60 \mathrm{~V}$ for $15 \mathrm{~min}$, then: in one case, the potentiostat was turned off and held at $E_{\text {cor }}$ for $4 \mathrm{~h}$, and in the other, the potential $E=0.2 \mathrm{~V}$ was set and held for $4 \mathrm{~h}$. After exposure, the surface of the samples was carefully washed with a stream of distilled water, washed in an ultrasonic bath, and transferred to the preliminary evacuation chamber of the spectrometer.

Corrosion studies of the alloy were carried out in distilled water with the addition of $0.01 \mathrm{M} \mathrm{NaCl}$ and different concentrations of the studied CIs. Before the experiment, MNZh 5-1 plates were cleaned on abrasive paper of various grain sizes (from P360 to P1000), degreased with acetone and weighed. The weighing accuracy was $0.00005 \mathrm{~g}$. Then 
the samples were placed in a chloride solution with additions of dicarboxylates of various concentrations at room temperature $t=(22 \pm 2)^{\circ} \mathrm{C}$ and natural aeration of the solution. After 7 days, the plates were removed, cleaned of corrosion products, and weighed again. From the difference in the plate masses before and after the tests, the corrosion rates in the background $\left(K_{0}\right)$ and inhibited solution $\left(K_{\text {inh }}\right)$ were calculated and the degree of metal protection $Z$ was determined by the formula:

$$
Z=\frac{K_{0}-K_{\text {inh }}}{K_{0}} \cdot 100 \%
$$

\section{Results and Discussion}

The polarization curves of the MNZh 5-1 alloy in a buffer solution containing $0.01 \mathrm{M} \mathrm{NaCl}$ and various additives of malonates are described in [15]. These measurements, carried out on the alloy, showed an advantage in the protective action of ethylmalonate over malonate, similar to how it happened on copper [14]. Comparison of the protective effect of homologues of sodium malonate and sodium adipate showed that these compounds spontaneously passivate the alloy in the potential region of the first peak of the anodic dissolution current density, $i_{\text {an }}$ at $E=0.15 \mathrm{~V}$ (Figure 2). In the region of the second peak of $i_{\text {an }}(E=0.35 \mathrm{~V})$, its potential decreases by $50-60 \mathrm{mV}$, and $i_{\text {an }}$ slightly increases in comparison with the background curve from 4.0 to $8 \mu \mathrm{A} / \mathrm{cm}^{2}$. Possibly, in this case, soluble complexes of organic anions with $\mathrm{Cu}^{2+}$ are formed. During the passage of the second peak of $i_{\text {an }}$, a passive state of the alloy is observed, which is disturbed by chlorides in the background solution at $E_{\mathrm{pt}}=0.59 \mathrm{~V}$.

The effect of inhibition of local depassivation by anions of dicarboxylic acids manifests itself in an increase in $E_{\mathrm{pt}}$, and its value significantly depends on their chemical structure. The effectiveness of sodium malonate as a depassivation inhibitor at $C_{\mathrm{inh}}=2 \mathrm{mmol} / \mathrm{L}$ is lower, compared to ethylmalonate and sodium adipate.

With a longer exposure of the copper alloy electrode in solution $(1 \mathrm{~h})$, the polarization curves have a different form: the first peak of the anodic dissolution of the alloy disappears on the background curve and $E_{\mathrm{pt}}$ shifts to the region of more positive values (Figure 2). At $E_{\text {cor }}$, dicarboxylic acids anions are adsorbed. The anodic polarization curve with the addition of sodium adipate with $C_{\text {inh }}=2 \mathrm{mmol} / \mathrm{L}$ (curve $4^{*}$ ) has a region of a stable state of the alloy with a shift of $E_{\mathrm{pt}}$ by $0.2 \mathrm{~V}$ relative to the curve obtained at 15 min exposure (curve 4 ) in an inhibited solution.

The reason for the superiority of sodium ethylmalonate and sodium adipate over sodium malonate is associated with the difference in their chemical structure, which determines their adsorbability and protective properties. It is known that their surface activity plays an important role in the efficiency of protection by organic CI of metals, including copper, in neutral aqueous media [23]. It largely depends on the hydrophobicity of CI, characterized by the value of $\log P$, where $P$ is the distribution coefficient of a chemical compound in a system of two immiscible octanol-water liquids [24]. The more positive the $\log P$ value, the 
higher the hydrophobicity of the compound; a negative $\log P$ value indicates its hydrophilicity. The $\log D$ value characterizes the hydrophobic/hydrophilic properties of the anion or cation, i.e. takes into account the influence of the charge arising from the dissociation or protonation of the corresponding organic molecules. It is calculated by the equation:

$$
\log D=\log P-\log \left[1+10\left(\mathrm{pH}-\mathrm{p} K_{\mathrm{a}}\right)\right],
$$

where $\log D$ is positive if the anion is hydrophobic and negative if it is hydrophilic.

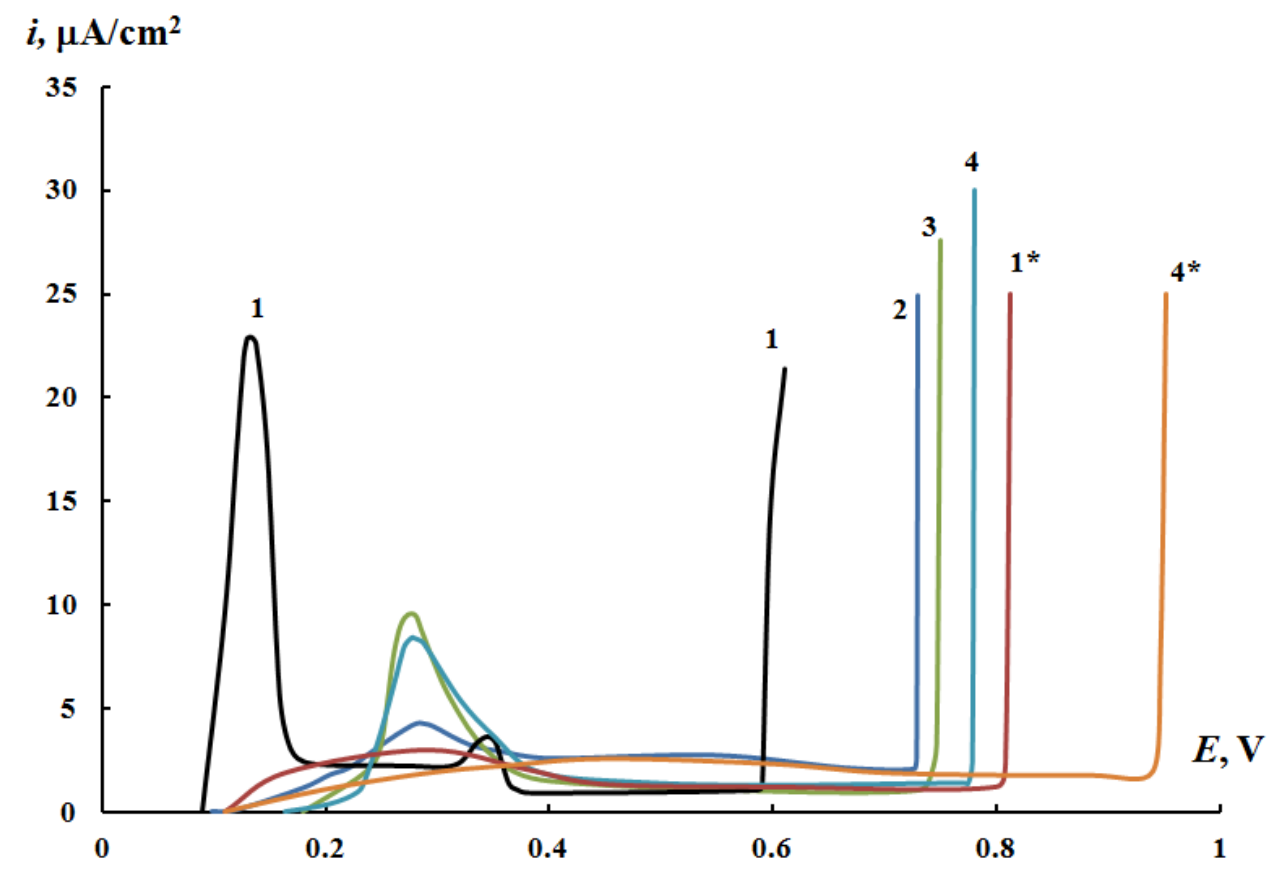

Figure 2. Anodic polarization curves of the MNZh 5-1 alloy in a borate buffer solution $\mathrm{pH} 7.4$ containing $0.01 \mathrm{M} \mathrm{NaCl}$ without $\left(1\right.$ and $1^{*}$ ) and with the addition of $C_{\mathrm{inh}}=2 \mathrm{mmol} / \mathrm{L}$ malonate (2), ethylmalonate (3), and sodium adipate (4 and $\left.4^{*}\right)$ at 15 minutes exposure in inhibitor solution and $1 *, 4^{*}$ : at 60 minutes exposure.

Table 1 shows the characteristics of the investigated IR, from which it is seen that sodium ethylmalonate and adipate have greater hydrophobicity and, therefore, surface activity, than sodium malonate.

The process of interaction of the dicarboxylate anion with the electrode surface, leading to the formation of a protective layer, is associated with the adsorption process. It was shown in [15] that on the oxidized surface of the alloy, sodium malonate and ethylmalonate anions are adsorbed in the same concentration range. Figure 3 shows the isotherms of their adsorption in comparison with the adsorption isotherm of sodium adipate, obtained under the same conditions. At $C_{\mathrm{inh}} \approx 0.006 \mathrm{nmol} / \mathrm{L}$, the adsorption of malonate and its substituted begins with the values of the maximum free adsorption energy $\left(-\Delta G_{\mathrm{a}, \max }^{0}\right)=74.1$ and $78.1 \mathrm{~kJ} / \mathrm{mol}$, respectively (Table 2 ). Such high values of $-\Delta G_{\mathrm{a}, \max }^{0}$ suggest their chemisorption on the alloy surface. Sodium adipate is adsorbed on the oxidized surface of 
MNZh 5-1 half an order of magnitude earlier than both malonates, while the value $-\Delta G_{\mathrm{a}, \max }^{0}$ is $81.8 \mathrm{~kJ} / \mathrm{mol}$.

Table 1. Physicochemical characteristics of dicarboxylic acids: acid dissociation constants $\mathrm{p} K_{\mathrm{a}}$, logarithm of distribution coefficients $(\log P)$. The $\mathrm{p} K_{\mathrm{a}}, \log D$ and $\log P$ values were obtained using the chemicalize.com resource.

\begin{tabular}{|c|c|c|c|}
\hline Dicarboxylic acid & $\log P$ & $\log D$ & $\mathrm{p} K_{\mathrm{a}}$ \\
\hline $\begin{array}{c}\text { Malonic acid } \\
\mathrm{HOOCCH}_{2} \mathrm{COOH}\end{array}$ & -0.33 & -5.34 & $\begin{array}{l}2.43 \\
5.92\end{array}$ \\
\hline $\begin{array}{c}\text { Ethylmalonic acid } \\
\mathrm{HOOCCH}\left(\mathrm{C}_{2} \mathrm{H}_{5}\right) \mathrm{COOH}\end{array}$ & 0.66 & -3.73 & $\begin{array}{l}2.50 \\
6.58\end{array}$ \\
\hline $\begin{array}{c}\text { Adipic acid } \\
\mathrm{HOOC}\left(\mathrm{CH}_{2}\right)_{4} \mathrm{COOH}\end{array}$ & 0.08 & -4.48 & $\begin{array}{l}4.43 \\
5.27\end{array}$ \\
\hline
\end{tabular}

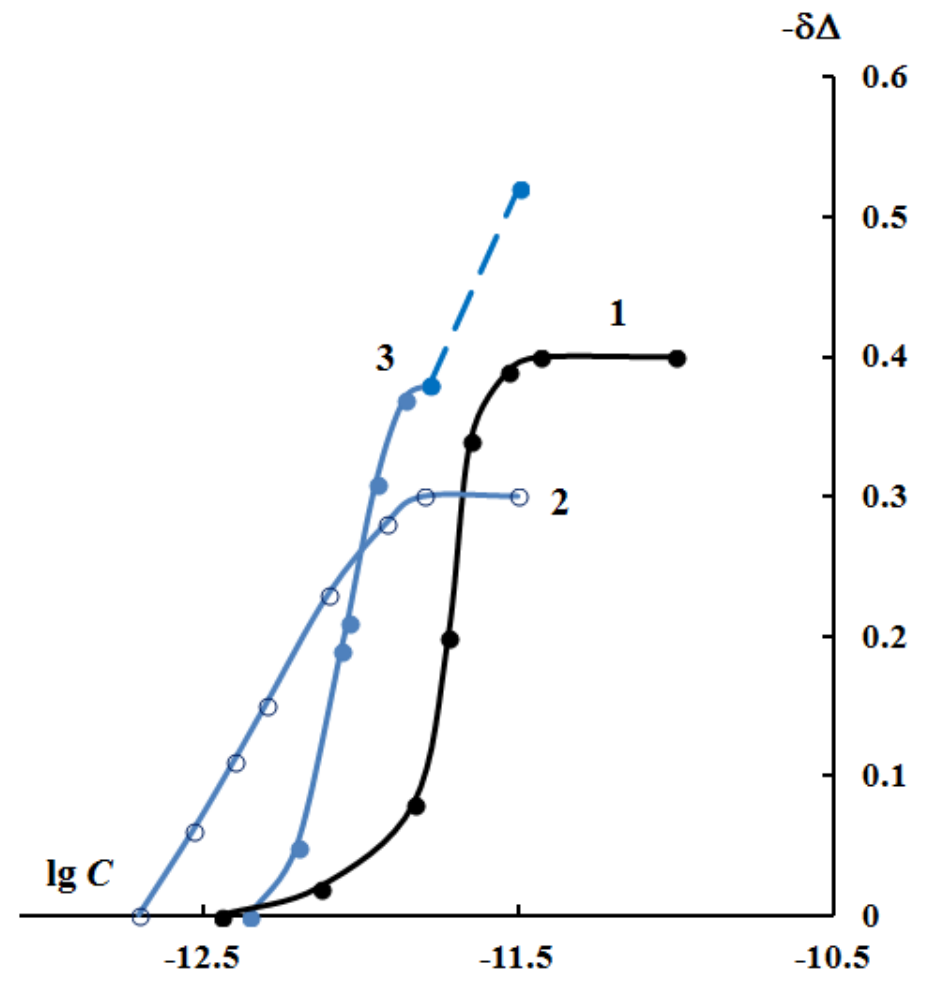

Figure 3. Dependence of the change in the ellipsometric angle $(-\delta \Delta)$ on the logarithm of the concentration of (1) malonate, (2) adipate, and (3) sodium ethylmalonate, on the oxidized surface of MNZh 5-1 at $E=0.0 \mathrm{~V}$ in a borate buffer $\mathrm{pH}$ 7.4. 
Table 2. Adsorption characteristics of isotherms for malonate, ethylmalonate and sodium succinate on the copper and MNZh 5-1 surface at potential $E=0.0 \mathrm{~V}$, steel and nickel at $E=0.2 \mathrm{~V}$ : minimum and maximum values of $B,-\Delta G_{\mathrm{a}, \max }^{0}$, and factor $f$.

\begin{tabular}{|c|c|c|c|c|c|c|}
\hline Inhibitor & Metal & $\begin{array}{c}B_{\mathrm{i}, \max } \\
\mathrm{L} / \mathrm{mol}\end{array}$ & $\begin{array}{c}B_{\mathrm{i}, \min } \\
\mathrm{L} / \mathrm{mol}\end{array}$ & $\begin{array}{l}-\Delta G_{\mathrm{a}, \text { min }}^{0} \\
\mathbf{k J} \mathbf{J} / \mathbf{m o l}\end{array}$ & $\begin{array}{c}-\Delta G_{\mathrm{a}, \max }^{0}, \\
\mathbf{k J} / \mathbf{m o l}\end{array}$ & $f$ \\
\hline \multirow{4}{*}{$\begin{array}{l}\text { Sodium } \\
\text { malonate }\end{array}$} & Copper & $0.43 \cdot 10^{7}$ & $0.08 \cdot 10^{7}$ & 43.6 & 47.7 & 1.65 \\
\hline & Steel & $1.12 \cdot 10^{5}$ & $1.46 \cdot 10^{4}$ & 33.7 & 37.7 & 2.15 \\
\hline & Nickel & $2 \cdot 10^{7}$ & $1 \cdot 10^{7}$ & 49.9 & 51.6 & 0.71 \\
\hline & MNZh 5-1 & $1.8 \cdot 10^{11}$ & $8.11 \cdot 10^{10}$ & 72.1 & 74.1 & 0.78 \\
\hline \multirow{4}{*}{$\begin{array}{l}\text { Sodium } \\
\text { ethylmalonate }\end{array}$} & Copper & $0.28 \cdot 10^{11}$ & $0.14 \cdot 10^{11}$ & 67.64 & 69.4 & 0.70 \\
\hline & Steel & $3.97 \cdot 10^{8}$ & $7.68 \cdot 10^{7}$ & 54.9 & 59.0 & 1.64 \\
\hline & Nickel & $3.47 \cdot 10^{10}$ & $5.86 \cdot 10^{9}$ & 65.6 & 70.0 & 1.77 \\
\hline & MNZh 5-1 & $9.06 \cdot 10^{11}$ & $5 \cdot 10^{11}$ & 76.60 & 78.1 & 0.59 \\
\hline \multirow{4}{*}{$\begin{array}{l}\text { Sodium } \\
\text { adipate }\end{array}$} & Copper & $4.9 \cdot 10^{9}$ & $1.6 \cdot 10^{9}$ & 62.5 & 65.2 & 1.10 \\
\hline & Steel & $2.86 \cdot 10^{6}$ & $8.2 \cdot 10^{6}$ & 46.8 & 49.4 & 1.05 \\
\hline & Nickel & $3.7 \cdot 10^{9}$ & $1.75 \cdot 10^{9}$ & 62.6 & 64.5 & 0.76 \\
\hline & MNZh 5-1 & $4 \cdot 10^{12}$ & $8.3 \cdot 10^{11}$ & 77.9 & 81.8 & 1.59 \\
\hline
\end{tabular}

The coefficient of energy inhomogeneity $f$ for the oxidized surface of the alloy during the adsorption of malonate and its substituted is lower than in the case of copper [15]). For malonate, $f=0.78$, and for ethylmalonate, $f=0.59$, these values indicate a more energetically homogeneous surface of mixed oxides on the alloy surface at a controlled potential.

The adsorption of dicarboxylates on the oxidized surface of nickel (Figure 4) and St3 (Figure 5) occurs in the region of higher concentrations than on the MNZh 5-1 alloy. The obtained adsorption constants of these compounds on various metals are given in Table 2.

Comparing the values $-\Delta G_{\mathrm{a}, \max }^{0}$ of dicarboxylates on the oxidized surface of the MNZh 5-1 alloy and its individual components: copper, nickel, and St3, one can note a clear increase in adsorption, probably caused by the heterogeneous surface of the MNZh 5-1 alloy. The enhancement of adsorption properties caused by an increase in free energy of adsorption of CIs on the oxidized surface of metals from a neutral buffer solution can be ranged as: St3 $<$ copper $\approx$ nickel $<$ MNZh 5-1 alloy.

For sodium ethylmalonate and adipate, one can assume the chemical character of the bond of their anions with the oxidized surface of St3 (Figure 5), which is less likely in the case of malonate. On the nickel surface at $E=0.2 \mathrm{~V}$, all studied salts are chemically adsorbed with values $-\Delta G_{\mathrm{a} \text {, max }}^{0}$ exceeding $40 \mathrm{~kJ} / \mathrm{mol}$ (Table 2 ). 


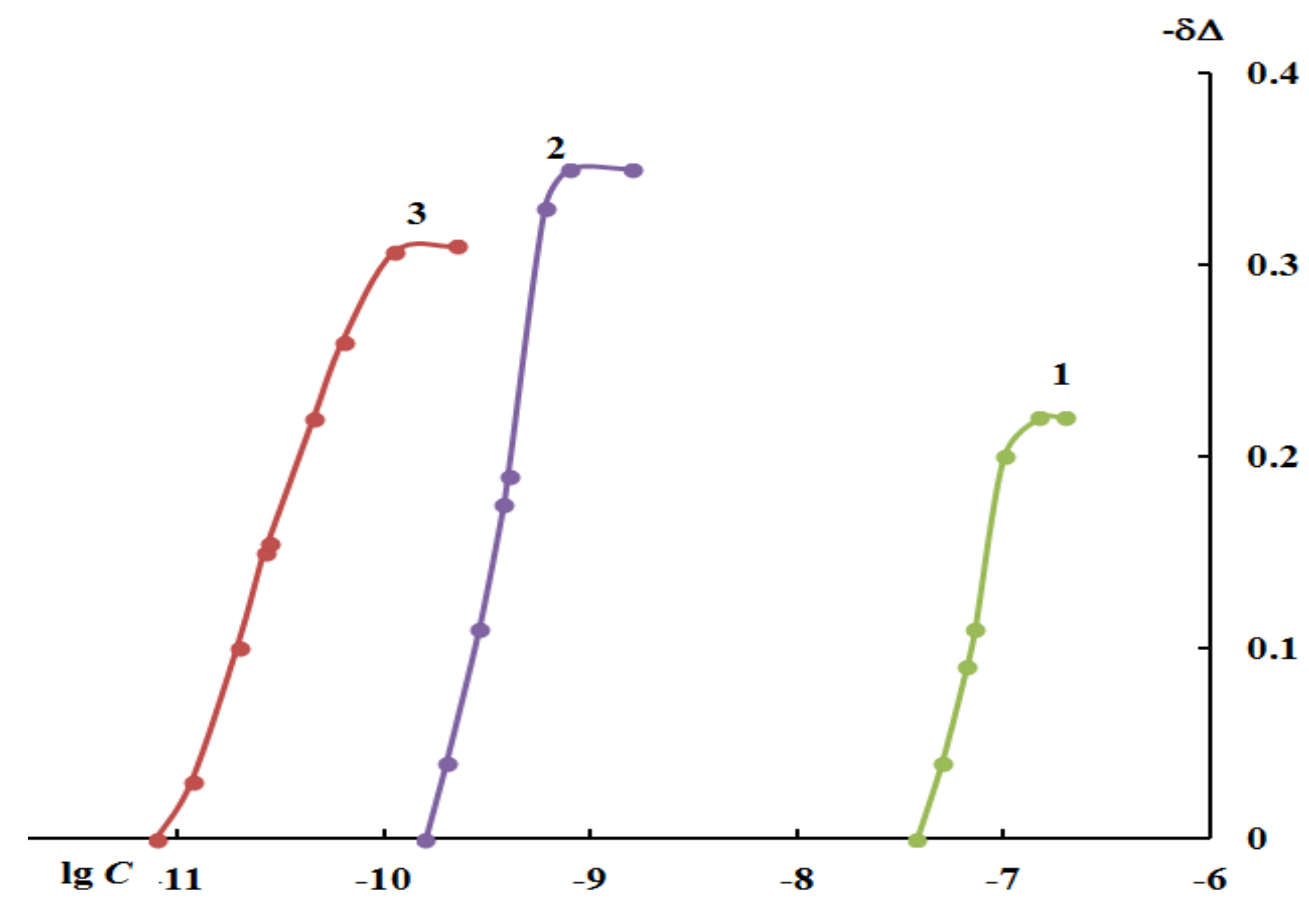

Figure 4. Dependence of the change in the ellipsometric angle $(-\delta \Delta)$ on the logarithm of the concentration of sodium (1) malonate, (2) adipate, and ethylmalonate (3) on oxidized nickel surface at $E=0.2 \mathrm{~V}$ in a borate buffer solution $\mathrm{pH}$ 7.4.

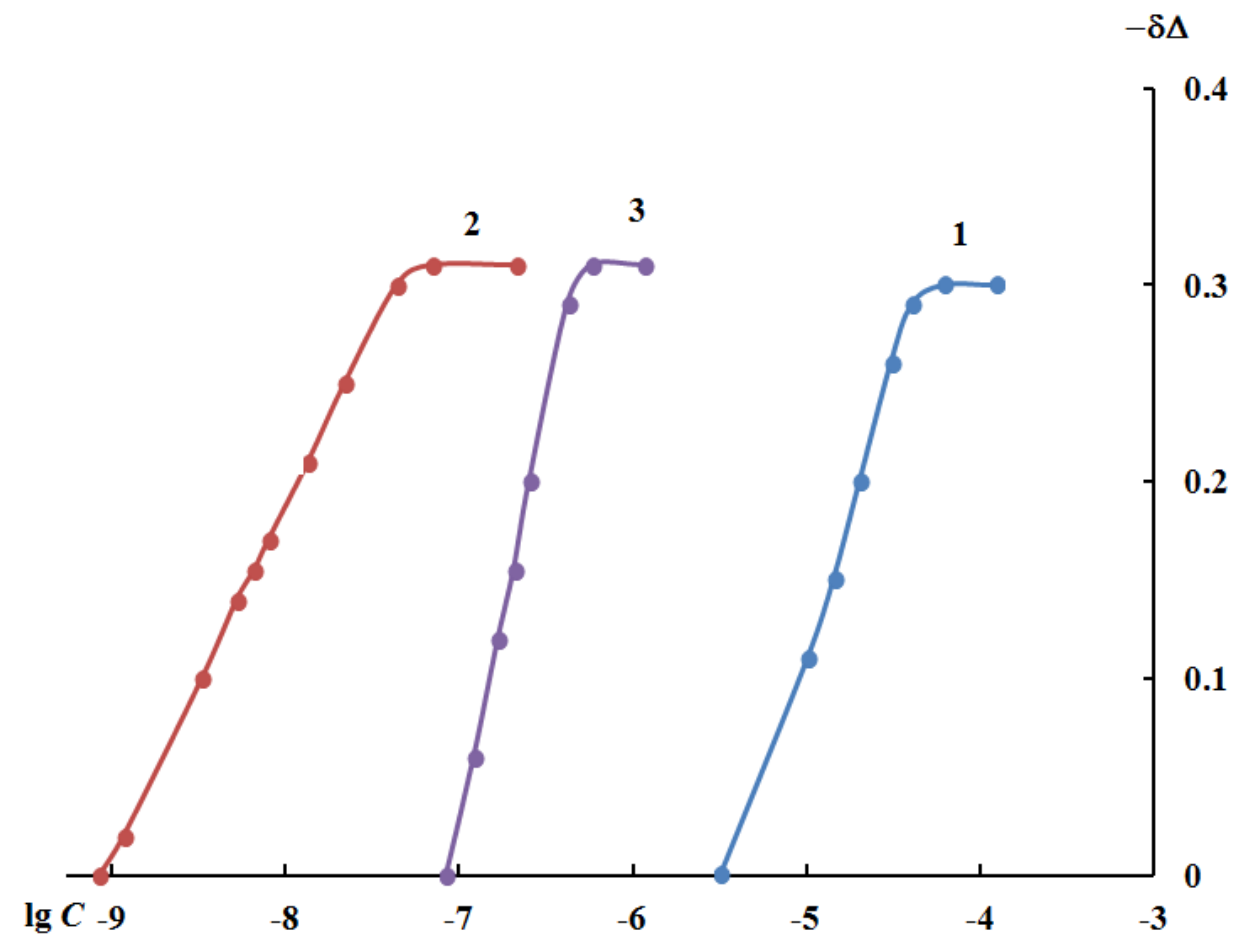

Figure 5. Dependence of the change in the ellipsometric angle $(-\delta \Delta)$ on the logarithm of the concentration of sodium (1) malonate, (2) adipate, and ethylmalonate (3) on oxidized St3 surface at $E=0.2 \mathrm{~V}$ in a borate buffer solution $\mathrm{pH}$ 7.4. 
Polarization measurements on St3, carried out in a borate buffer with the addition of $0.01 \mathrm{M} \mathrm{NaCl}$, showed that all three compounds are unable to spontaneously passivate the steel electrode in the entire studied range of $C_{\text {inh }}$ concentrations from 1 to $7 \mathrm{mmol} / \mathrm{L}$. Anodic polarization curves at $C_{\text {inh }}=2 \mathrm{mmol} / \mathrm{L}$ are shown in Figure 6. From their consideration, it follows that there is a decrease in the peak of anodic dissolution of low-carbon steel only in the case of sodium adipate, while malonate and ethylmalonate increase the currents by 32 and $14 \mu \mathrm{A} / \mathrm{cm}^{2}$, respectively. Only sodium adipate and ethylmalonate are able to prevent local depassivation of steel by chloride ions, shifting $E_{\mathrm{pt}}$ towards positive values in the presence of sodium adipate more than in the case of substituted malonate. It is possible that the lengthening of the hydrocarbon chain plays a role here and, thus, a greater degree of surface shielding, as well as a higher value of the hydrophobicity coefficient of the compound than sodium malonate (Table 1).

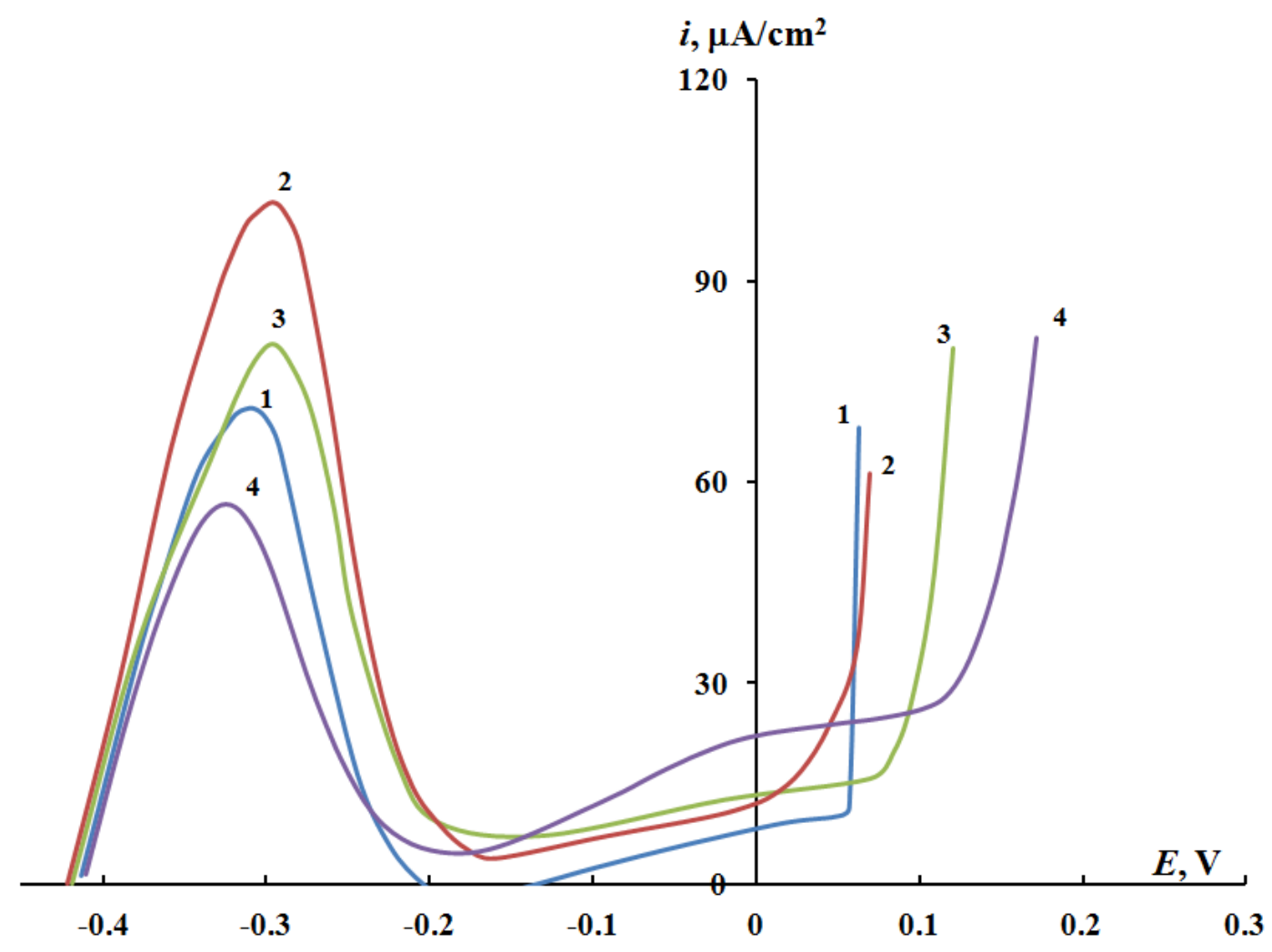

Figure 6. Anodic polarization curves of St3 with additions of dicarboxylates with $C_{\mathrm{inh}}=$ $2 \mathrm{mmol} / \mathrm{L}$ in a borate buffer solution $\mathrm{pH} 7.4$ with a $0.01 \mathrm{M} \mathrm{NaCl}$ : 1 - background,

2 - sodium malonate, 3 - sodium ethylmalonate, 4 - sodium adipate.

Polarization curves for nickel in a chloride buffer solution are shown for one $C_{\text {inh }}=5 \mathrm{mmol} / \mathrm{L}$ (Figure 7). For sodium malonate and adipate, the local depassivation potential is improved by 0.07 and $0.13 \mathrm{~V}$, respectively.

Earlier, when studying the anodic polarization of nickel [11, 12, 25], it was shown that CI triazole type, such as BTA and 5-chloroBTA, are able to effectively inhibit metal 
corrosion in a neutral chloride buffer. For the compounds studied by us, the hydrophobicity is much lower than for triazoles, which is probably why such a high value of the protective effect is not observed.

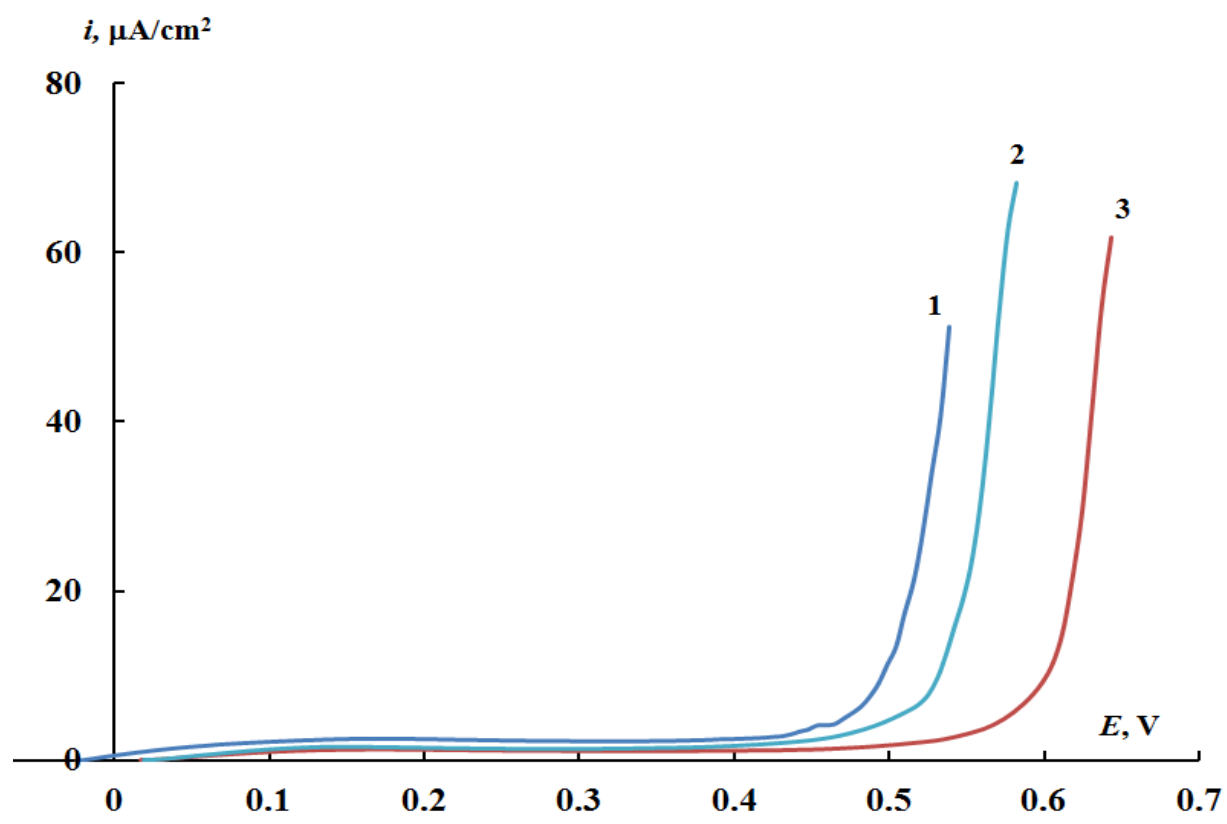

Figure 7. Anodic polarization curves of nickel with additions of dicarboxylates with $C_{\mathrm{inh}}=5 \mathrm{mmol} / \mathrm{L}$ in a borate buffer solution $\mathrm{pH} 7.4$ containing $0.01 \mathrm{M} \mathrm{NaCl}: 1$ - background, 2 - sodium malonate, 3 - sodium adipate.

Analyzing the results of electrochemical and ellipsometric studies, it can be noted that dicarboxylates with higher hydrophobicity (sodium ethylmalonate and sodium adipate) are superior to hydrophilic malonate in inhibiting the alloy and its individual components.

We studied the surface layers of the alloy by the XPS method, the results of the study are shown in Figures 8 and 9. According to XPS, on the spectrum of copper $\mathrm{Cu} 2 \mathrm{p}$ electrons (Figure 9) in the region of $948-940 \mathrm{eV}$ there is a $\mathrm{Cu}^{+}$satellite, the positions of the spin-orbit splitting peaks are $932.1 \mathrm{eV}$ for $\mathrm{Cu} 2 \mathrm{p} 3 / 2$ and $951.9 \mathrm{eV}$ for $\mathrm{Cu} 2 \mathrm{p} 1 / 2$. Due to the fact that this spectrum is difficult to separate, since the positions for $\mathrm{Cu}^{0}$ and $\mathrm{Cu}_{2} \mathrm{O}$ practically coincide with each other, Auger spectra of copper CuLMM are presented. According to these spectra, the main component of the alloy, copper, is in the metallic [26] and cuprite [27] states both at the potential of free corrosion and at $E=0.2 \mathrm{~V}$. It should be noted that an increase in the signal intensity is observed in the samples held at $E=0.2 \mathrm{~V}$, which is probably due to the enrichment of the sample surface with copper, while the thickness of hydrocarbon contaminants in both samples is about $2 \mathrm{~nm}$, as well as an increase in the cuprite component of the spectrum.

In turn, on the spectra of metals (Figure 9): iron and nickel, in addition to a decrease in their intensity, a change in the states of these elements is observed. In the spectrum of iron $\mathrm{Fe} 2 \mathrm{p} 3 / 2$ and nickel Ni2p3/2-electrons at the potential of free corrosion, peaks of metals $\mathrm{Fe}^{0}$ and $\mathrm{Ni}^{0}$ are observed with positions 707.0 [28] and $852.4 \mathrm{eV}$ [29], respectively. The states 
of $\mathrm{FeO}[30,31]$ with a binding energy of $710.2 \mathrm{eV}$ and $\mathrm{FeO}(\mathrm{OH})$ or $\mathrm{Fe}_{2} \mathrm{O}_{3}$ are observed both at the potential of free corrosion and at $0.2 \mathrm{~V}$; satellites for $\mathrm{Fe}^{2+}$ and $\mathrm{Fe}^{3+}$ are also observed. A similar situation is typical for the spectrum of nickel Ni2p3/2-electrons, which also exhibits peaks corresponding to nickel oxide $\mathrm{NiO}$ [32] with position $854.3 \mathrm{eV}$ and nickel hydroxide $856.3 \mathrm{eV}$ [33].

Analyzing the results of elemental analysis and electrochemical studies, one can come to the conclusion that the iron component of the MNZh 5-1 alloy reduces the alloy's resistance to the aggressive action of chloride ions. This fact is also confirmed by polarization measurements, when none of the studied salts is able to spontaneously passivate low-carbon steel.

It is of particular interest to evaluate the protective ability of sodium salts of dicarboxylic acids in relation to the MNZh 5-1 alloy in corrosion tests. They were carried out in an aqueous solution of $0.01 \mathrm{M} \mathrm{NaCl}$ on alloy plates for 7 days.
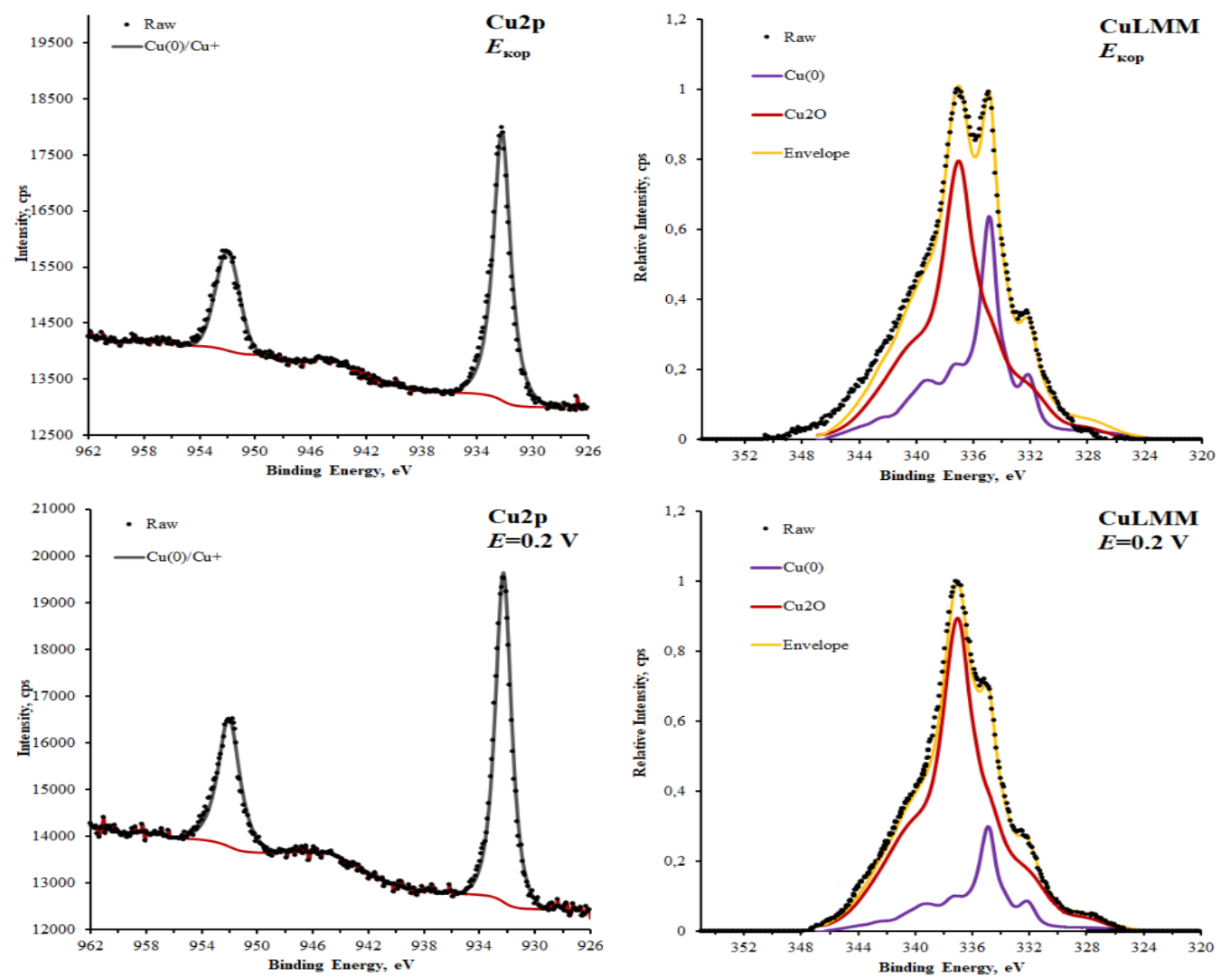

Figure 8. Spectra of Cu2p and CuLMM electrons of a sample of the MNZh 5-1 alloy after exposure to solutions at $E_{\text {cor }}$ and $E=0.2 \mathrm{~V}$. 

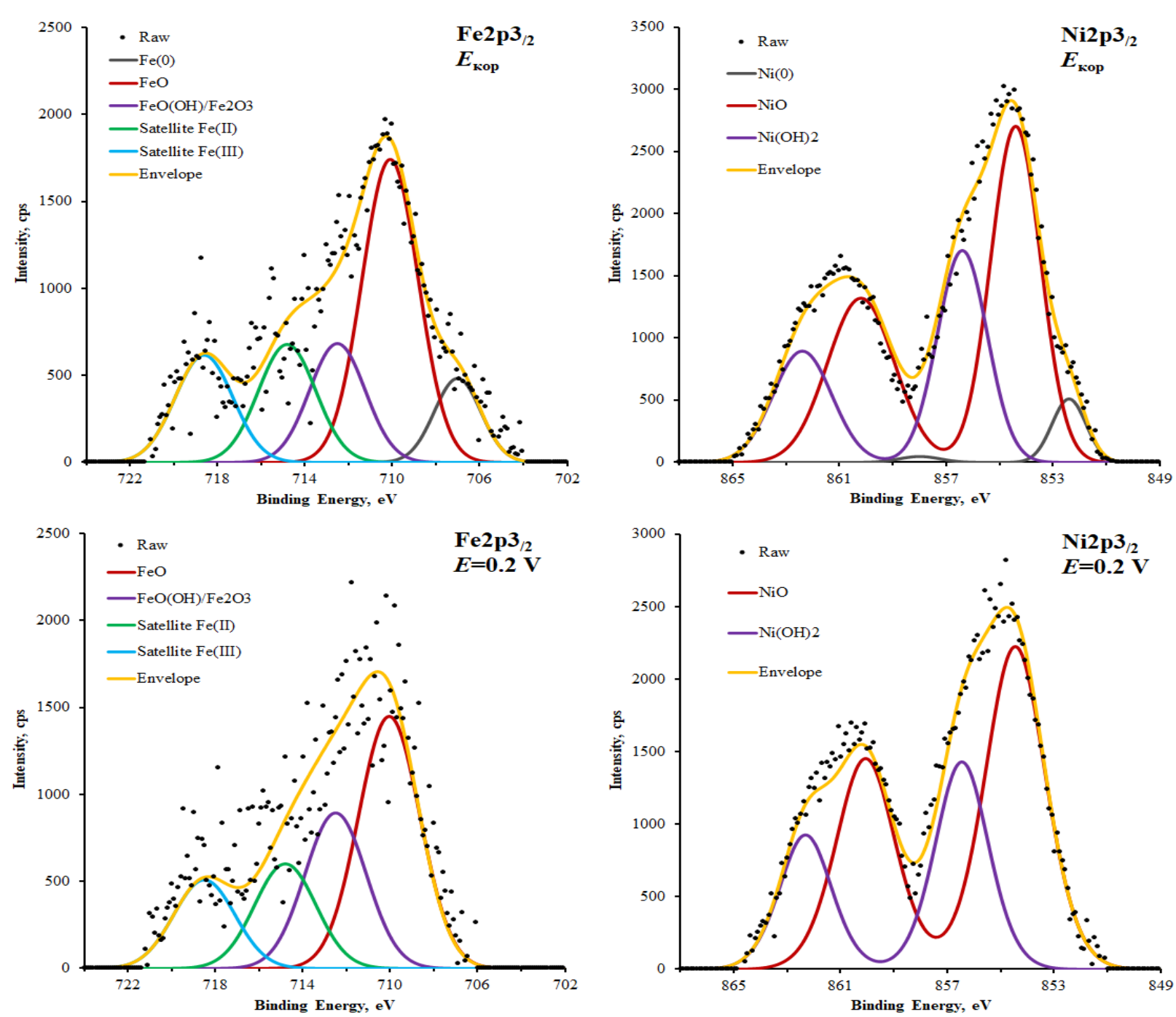

Figure 9. Spectra of Fe2p3/2- and Ni2p3/2-electrons of the MNZh 5-1 alloy sample after exposure to solutions at $E_{\text {cor }}$ and $E=0.2 \mathrm{~V}$.

On the MNZh 5-1 alloy in a $0.01 \mathrm{M}$ chloride solution in the concentration range of $0.2-$ $5.0 \mathrm{mmol} / \mathrm{L}$, sodium malonate and ethylmalonate are not able to suppress the corrosion of alloy plates. Sodium adipate at $C_{\mathrm{inh}}=1 \mathrm{mmol} / \mathrm{L}$ provides a degree of protection $Z=32 \%$, at $C_{\text {inh }}=2 \mathrm{mmol} / \mathrm{L} Z=43 \%$ and at $C_{\text {inh }}=3 \mathrm{mmol} / \mathrm{L} Z=49 \%$. Such a low protective effect of dicarboxylates on the alloy can be caused by the heterogeneity of the latter and the possibility of the formation of soluble CI complexes with metal cations, for example, iron. In this regard, we investigated the possibility of increasing the effectiveness of their protective action using a mixture of sodium adipate with a small addition of 2-mercaptobenzthiazole (2-MBT) in a ratio of 9:1 on samples of the MNZh 5-1 alloy in the same sodium chloride solution (Figure 10). The results of these studies are shown in Figure 8 in the form of the dependence of the degree of protection of the metal on the concentration of adipate and its mixture with 2-MBT. 


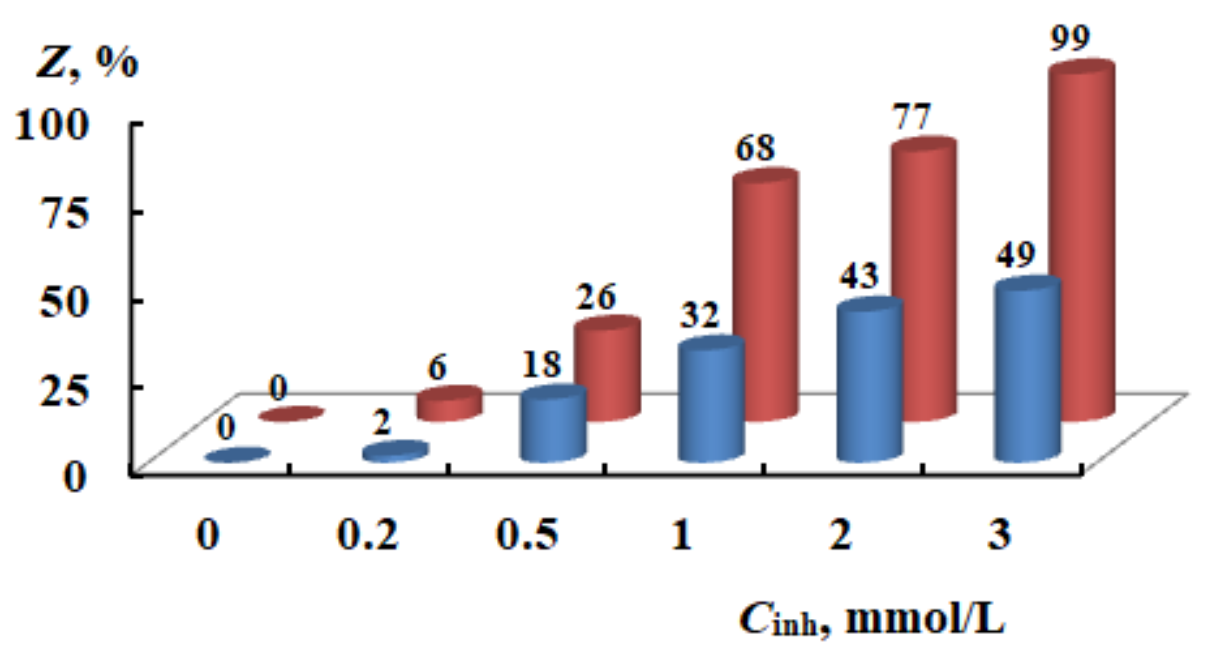

Figure 10. Dependence of the degree of corrosion protection of the MNZh 5-1 alloy on the concentration of sodium adipate (blue columns) and its formulation with 2-MBT $(9: 1)$ (red columns) in aqueous solution with $0.01 \mathrm{M} \mathrm{NaCl}$.

It is known that 2-MBT is a compound poorly soluble in water, and alkalinization of the solution is used to increase its solubility $[34,35]$. To create an inhibitory mixture, solutions of sodium adipate and 2-MBT were taken in a ratio of 9:1, respectively. At the same time, constant monitoring of the $\mathrm{pH}$ value was carried out during the experiment. The

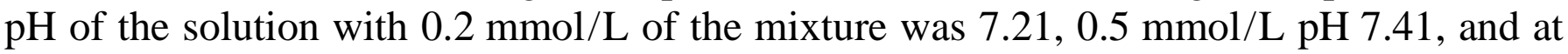
$3 \mathrm{mmol} / \mathrm{L} \mathrm{pH} 8.02$.

Already the addition of $0.2 \mathrm{mmol} / \mathrm{L}$ of the formulation of sodium adipate with 2-MBT $(9: 1)$ provides a small degree of protection of the alloy $(Z=6 \%)$, although adipate itself does not protect the alloy at this concentration. At $1.0 \mathrm{mmol} / \mathrm{L}$ of the formulation, the $Z$ value increases by more than an order of magnitude and more than 2 times higher than the degree of protection by the adipate itself. At $C_{\mathrm{inh}}=3 \mathrm{mmol} / \mathrm{L}$ of the mixture, $Z$ reaches $99 \%$, i.e. corrosion is almost completely suppressed, and adipate does not provide $Z=50 \%$ at the same $C_{\text {inh. }}$. Consequently, the introduction of even a very small additive of 2-MBT to dicarboxylates can dramatically increase their protective properties with respect to the alloy under study in a chloride solution.

\section{Conclusions}

1. The adsorption of sodium salts of ethylmalonic and adipic acids on the oxidized surface of the MNZh 5-1 alloy, nickel and St3 is of a chemical nature. The enhancement of the adsorption of dicarboxylates on the alloy in comparison with copper can probably be explained by the heterogeneous surface of the alloy. The adsorption properties of the studied anions of dicarboxylic acids on the oxidized surface of metals increase in the following order: St3 < copper $\approx$ nickel $<$ MNZh 5-1 alloy. 
2. Anions of dicarboxylates are able to passivate nickel in a chloride buffer solution; for all salts, an increase of $E_{\mathrm{pt}}$ is observed in the range of $0.55-0.63 \mathrm{~V}$. In the case of St3, no spontaneous passivation is observed, but the value of $E_{\mathrm{pt}}$ increases by $\sim 0.08-0.18 \mathrm{~V}$ in the presence of sodium adipate or ethylmalonate, which indicates, albeit weakly, that they prevent local depassivation of steel by chlorides. Sodium adipate increases $E_{\mathrm{pt}}$ more strongly than other studied dicarboxylates.

3. Using the XPS method, it is shown that at the potential of free corrosion, the surface of a copper-nickel alloy is enriched with iron, which reduces the resistance of the alloy to the action of chloride ions on it.

4. Corrosion tests of the alloy in a chloride solution for 7 days showed that it is possible to enhance the protective effect of salts of lower dicarboxylic acids with the help of 2-MBT additives. The sodium adipate +2 -MBT formulation $(9: 1)$ increases the degree of protection of the alloy by more than 2 times at $1.0 \mathrm{mmol} / \mathrm{L}$, and at $3 \mathrm{mmol} / \mathrm{L}$ the formulation provides complete protection against corrosion of $\mathrm{MNZh} \mathrm{5-1} \mathrm{in} \mathrm{a} \mathrm{chloride}$ solution for 7 days.

\section{References}

1. R.K. Dinnappa and S.M. Mayanna, The dezincification of brass and its inhibition in acidic chloride and sulphate solutions, Corros. Sci., 1987, 27, 349-361. doi: 10.1016/0010-938X(87)90077-1

2. M. Mihit, S. El Issami, M. Bouklah, L. Bazzi, B. Hammouti, E. Ait Addi, R. Salghi and S. Kertit, The inhibited effect of some tetrazolic compounds towards the corrosion of brass in nitric acid solution, Appl. Surf. Sci., 2006, 252, 2389-2395. doi: 10.1016/j.apsusc.2005.04.009

3. J. Jennane, M.E. Touhami, S. Zehra, Y. Baymou, S.-H. Kim, I.-M. Chung and H. Lgaz, Influence of sodium gluconate and cetyltrimethylammonium bromide on the corrosion behavior of duplex $(\alpha-\beta)$ brass in sulfuric acid solution, Mater. Chem. Phys., 2019, 227, 200-210. doi: 10.1016/j.matchemphys.2019.02.001

4. T. Kosec, I. Milošev and B. Pihlar, Benzotriazole as an inhibitor of brass corrosion in chloride solution, Appl. Surf. Sci., 2007, 253, 8863-8873. doi: 10.1016/j.apsusc.2007.04.083

5. H.-Q. Fan, D.-D. Shi, M.-M. Ding, M.-C. Li, Y.F. Cheng and Q. Li, Preparation of (3mercaptopropyl)trimethoxylsilane film on brass and its corrosion resistance in natural seawater, Prog. Org. Coat., 2020, 138, 105392. doi: 10.1016/j.porgcoat.2019.105392

6. M. Finšgar, Electrochemical, 3D topography, XPS, and ToF-SIMS analyses of 4methyl-2-phenylimidazole as a corrosion inhibitor for brass, Corros. Sci., 2020, 169, 108632. doi: $10.1016 /$ j.corsci.2020.108632

7. K. Ramji, D.R. Cairns and S. Rajeswari, Synergistic inhibition effect of 2mercaptobenzothiazole and Tween-80 on the corrosion of brass in $\mathrm{NaCl}$ solution, Appl. Surf. Sci., 2008, 254, 4483-4493. doi: 10.1016/j.apsusc.2008.01.031 
8. B. Müller, Corrosion inhibition of different metal pigments in aqueous alkaline media, Corros. Sci., 2001, 43, 1155-1164. doi: 10.1016/S0010-938X(00)00134-7

9. Yu.I. Kuznetsov and L.P. Kazansky, Physicochemical aspects of metal protection by azoles, Russ. Chem. Rev., 2008, 77, no. 3, 219-232. doi: 10.1070/RC2008v077n03ABEH003753

10. S.A. Umoren and M.M. Solomon, Synergistic corrosion inhibition effect of metal cations and mixtures of organic compounds: A Review, J. Environ. Chem. Eng., 2017, 5, 246-273. doi: 10.1016/j.jece.2016.12.001

11. Yu.I. Kuznetsov, N.P. Andreeva and M.O. Agafonkina, Adsorbtsiya i zashchitnye svoistva 1,2,3-benzotriazola na splave MNZh 5-1 v neitral'nykh rastvorakh, Elektrokhimiya (Electrochemistry), 2014, 50, no. 10, 1100-1105 (in Russian). doi: 10.7868/S0424857014100041

12. Yu.I. Kuznetsov, M.O. Agafonkina, N.P. Andreeva, I.A. Arkhipushkin and L.P. Kazanskii, Ingibirovanie korrozii splava MNZh 5-1 v neitral'nykh rastvorakh 5khlor-1,2,3-benzotriazola, Zh. Fiz. Khim., 2017, 91, no. 11, 1937-1944 (in Russian). doi: $\underline{10.7868 / \mathrm{S} 0044453717110140}$

13. M.O. Agafonkina, Yu.I. Kuznetsov and N.P. Andreeva, Adsorbtsiya anionov karbonovykh kislot na splave MNZh 5-1 iz neitral'nykh vodnykh rastvorov, Korroz.: mater., zashch. (Corrosion: materials, protection), 2019, no. 8, 29-35 (in Russian). doi: $\underline{\text { 10.31044/1813-7016-2019-0-8-29-34 }}$

14. M.O. Agafonkina, I.A. Kuznetsov, N.P. Andreeva and Yu.I. Kuznetsov, Copper protection with sodium salts of lower dicarboxylic acids in neutral aqueous solution, Int. J. Corros. Scale Inhib., 2020, 9, no. 3, 1000-1013. doi: 10.17675/2305-6894-2020-9-3$\underline{13}$

15. N.P. Andreeva, I.A. Kuznetsov, Yu.I. Kuznetsov and M.O. Agafonkina, Zashchita medi i ee splava MNZh 5-1 natrievymi solyami malonovoi i etilmalonovoi kislot v neitral'nom khloridnom rastvore, Korroz.: mater., zashch. (Corrosion: materials, protection), 2021, no. 1, 33-42 (in Russian).

16. I. Dugdale and J.B. Cotton, An electrochemical investigation on the prevention of staining of copper by benzotriazole, Corros. Sci., 1963, 3, no. 2, 69-74. doi: 10.1016/S0010-938X(63)80001-3

17. G.T. Hefter, N.A. North and S.H. Tan, Organic corrosion inhibitors in neutral solutions. Part 1. Inhibition of steel, copper and aluminum by straight chain carboxylates, Corrosion, 1997, 53, 657-667. doi: 10.5006/1.3290298

18. N.Y. Bashkirceva, O.Y. Sladovskya, Y.S. Ovchinnikova and B.R. Vagapov, Anticorrosion properties of carboxylic acid in water-glycol solutions, Int. Res. J., 2012 (in Russian). doi: 10.18454/IRJ.2227-6017

19. R.M. Azzam and N.M. Bashara, Ellipsometry and Polarized Light, North-Holland, Amsterdam, 1977, 529. 
20. M.O. Agafonkina, N.P. Andreeva, Yu.I. Kuznetsov and S.F. Timashev, Substituted Benzotriazoles as Inhibitors of Copper Corrosion in Borate Buffer Solutions, Russ. J. Phys. Chem. A, 2017, 91, no. 8, 1414-1421. doi: 10.1134/S0036024417080027

21. D.A. Shirley, High-Resolution X-Ray Photoemission Spectrum of the Valence Bands of Gold, Phys. Rev. B, 1972, 5, 4709-4713.

22. J.H. Scofield, Hartree-Slater subshell photoionization cross-sections at 1254 and 1487 eV, J. Electron Spectrosc. Relat. Phenom., 1976, 8, 129-137. doi: 10.1016/03682048(76)80015-1

23. Yu.I. Kuznetsov, Organic inhibitors of corrosion of metals, 1996, New York, Plenum Press, 283.

24. C. Hanch and A. Leo, Substituent Constants for Correlation Analysis in Chemistry and Biology, 1979, New York: Wiley-Interscience, 339.

25. N.P. Andreeva, Yu.Ya. Andreev, L.I. Esina and Yu.I. Kuznetsov, Stabilizatsiya passivnogo sostoyaniya nikelya adsorbtsiei 1,2,3-benzotriazolov v neitral'nom rastvore, Korroz.: mater., zashch. (Corrosion: materials, protection), 2013, no. 1, 13-19 (in Russian).

26. C. Battistoni, G. Mattogno, E. Paparazzo and L. Naldini, An XPS and Auger study of some polynuclear copper compounds, Inorg. Chim. Acta., 1985, 102, no. 1, 1-3. doi: 10.1016/S0020-1693(00)89066-0

27. C.E. Dube, B. Workie, S.P. Kounaves, A. Robbat, M.L. Aksu and G. Davies, Electrodeposition of Metal Alloy and Mixed Oxide Films Using a Single-Precursor Tetranuclear copper-nickel Complex, J. Electrochem. Soc., 1995, 142, no. 10, 33573365.

28. H.J. Mathieu and D. Landolt, An investigation of thin oxide film thermally grown in situ on Fe-24Cr and Fe-24Cr-11Mo by Auger electron spectroscopy and X-ray photoelectron spectroscopy, Corros. Sci., 1986, 26, no. 7, 547-559. doi: 10.1016/0010938X(86)90022-3

29. K. Lian, D.W. Kirk and S.J. Thorpe, Electrocatalytic behaviour of Ni-base amorphous alloys, Electrochim. Acta, 1991, 36, 537-545. doi: 10.1016/0013-4686(91)85138-W

30. D.D. Hawn and B.M. De Koven, Deconvolution as a correction for photoelectron inelastic energy losses in the core level XPS spectra of iron oxides, Surf. Interface Anal., 1987, 10, 63. doi: 10.1002/sia.740100203

31. N.S. McIntyre and D.G. Zetaruk, X-ray Photoelectron Spectroscopic Studies of Iron Oxide, Anal. Chem., 1977, 49, no. 11, 1521-1529. doi: 10.1021/ac50019a016

32. E. Khawaja, M. Salim, M. Khan, F. Al-Adel, G. Khattak and Z. Hussain, XPS, auger, electrical and optical studies of vanadium phosphate glasses doped with nickel oxide, $J$. Non-Cryst. Solids, 1989, 110, 33-43. doi: 10.1016/0022-3093(89)90179-8

33. C.L. Bianchi, M.G. Cattania and P. Villa, XPS characterization of Ni and Mo oxides before and after "in situ" treatments, Appl. Surf. Sci., 1993, 70, 211-216. doi: $\underline{10.1016 / 0169-4332(93) 90429-\mathrm{F}}$ 
34. Yu.I. Kuznetsov, M.O. Agafonkina, N.P. Andreeva and D.B. Vershok, Adsorption of 2mercaptobenzthiazol on copper and MNZh-5-1 alloy and their protection from corrosion in aqueous solutions, Int. J. Corros. Scale Inhib., 2020, 9, no. 1, 344-361. doi: 10.17675/2305-6894-2020-9-1-23

35. Yu.I. Kuznetsov, I.A. Kuznetsov and D.B. Vershok, Copper corrosion protection in neutral media by dicarboxylic acid salts, Int. J. Corros. Scale Inhib., 2019, 8, no. 4, 1022-1034. doi: 10.17675/2305-6894-2019-8-4-13 